\title{
THE PSYCHOSOCIAL FACTORS AT WORK RELATED TO DEPRESSION AMONG FEMALE WHITE-COLLAR WORKERS IN VILNIUS (LITHUANIA)
}

\section{JELENA STANISLAVOVIENE ${ }^{1}$, BIRUTE PAJARSKIENE ${ }^{1}$, REMIGIJUS JANKAUSKAS ${ }^{1}$, and MARIJA VENIUTE ${ }^{2}$}

${ }^{1}$ Institute of Hygiene, Vilnius, Lithuania

${ }^{2}$ Vilnius University, Vilnius, Lithuania

Faculty of Medicine

\begin{abstract}
Objectives: The aim of this study is to establish which psychosocial factors at work are related to depression among female white-collar workers in Vilnius. Materials and Methods: The data was collected in a case-control study in 2002-2004. The cases were selected from patients treated at Vilnius mental health centers. The controls were randomly selected from employed Vilnius residents. A descriptive statistic and logistic regression was applied. Results: 3 psychosocial factors and possible confounders within the evaluated model were statistically reliable (model $\chi^{2}: 44.47, \mathrm{p}<0.05$ ). The adjusted odds ratio for uneven work distribution was 2.17 (95\% CI: 1.38-3.51, $\mathrm{p}<0.005)$, the odds ratio for possibility to control was 10.81 (95\% CI: 2.13-54.71, $\mathrm{p}<0.005$ ), and the odds ratio for family esteem was 2.13 (95\% CI: 1.01-4.59, $\mathrm{p}<0.005$ ). Conclusion: This study suggests that work distribution, possibility to control and family esteem, together with stressful life events and mental health disorders in the family, are related to depression among female white-collar workers.
\end{abstract}

Key words:

Psychosocial factors at work, Depression, Vilnius

\section{INTRODUCTION}

In the modern society the impact of three factors - biological, psychological and social is considered to be significant for mental health maintenance and development of mental disorders. It is especially important in Lithuania where until now the greatest attention has been paid to the medical treatment of mental illnesses. Therefore, it is very important to give enough attention to the environment where people spend most of their time at school, with family, and at their workplaces. This attitude is reflected in both international and domestic political documents in the form of Mental Health Strategy of Lithuania and Community Strategy 2007-2012 on Health and Safety at Work [1,2].
According to the data of the International Labor Organization, disorders of working people are more costly for the society than those of any other social groups [3,4]. It is not only related to medical costs (hospitalizations, medications), but also to indirect expenses incurred due to sickness (sickbenefits, family members dropout from the labor market in order to take care of the sick family member) and reduced working capacity. Depression occurs among working people more often than any other mental disorders. The data of the Occupational Medicine Centre shows that about 15.3\% of the working females in Vilnius - the capital of Lithuania - show depressive symptoms [5]. As revealed by a national survey of the Lithuania's Department of Statistics carried out in 2005, $6 \%$ of the adult respondents marked

Received: October 27, 2009. Accepted: March 14, 2011.

Address reprint request to J. Stanislavoviene, Institute of Hygiene, Didzioji st. 22, Vilnius, LT-01128, Lithuania (e-mail: elena@vpsc.lt). 
chronic anxiety or depression in the list of diseases provided to them as the ones that they were diagnosed with [6].

Depression often disturbs our social life, as an incessantly ill person cannot study, take care of the house, or handle personal relationships. It also influences people's working life. It can manifest itself in an increase in occupational accidents and the quantity of mistakes, as well as a decrease in motivation and responsibility. Absenteeism and alcoholism become more frequent. It should be highlighted that alcohol consumption per year per capita in Lithuania is one of the highest in Europe [7]. The number of alcoholic psychosis incidents has rapidly grown, ranging from 51.1/100 000 in 1999, through 80.8/100 000 in 2004, to finally reach 111.9/100 000 incidents in 2008 [8].

Obviously, mental health diseases diminish working capacity. They also have one significant feature. They are very often disguised and remain untreated. Untreated depression often progresses, culminating in a relapse or further complications. One of its most painful complications is suicide. Since 1994, Lithuania has had one of the highest suicide rates in Europe. In 2002, the suicide rate for women was 13.1/100 000. Despite the fact that these numbers have decreased a little, they are still very high - 10.8/100 000 in the year 2008 [9].

Bearing in mind that Lithuania has gone through significant changes within the last 15 years in the spheres of economy and labor, simultaneously exhibiting rather poor indicators of mental health, it is important to establish which psychosocial factors at work are connected with depression, as it is one of the most widespread mental diseases.

\section{MATERIALS AND METHODS}

The study was performed in Vilnius, the capital of Lithuania, during the years 2002-2004. The population of Vilnius during these years equaled about 500 000, out of which around 370000 people were employed. The proportion of male and female workers was similar.
The psychosocial factors at work related to depression were studied using a case-control method. The permission to conduct this study was received from the Lithuanian Bioethics Committee.

\section{Sampling procedure}

The cases were selected from patients treated at Vilnius mental health centers. The criteria for inclusion were a clinical diagnosis of the first depression episode, coded in the medical documentation as F32, according to the 10th revision of the International Classification of Diseases (ICD-10), voluntary agreement to take part in the study, current employment for a period of no less than 1 year, and a fulltime job at only one workplace.

The controls were randomly selected from employed Vilnius residents. First, 100 streets were randomly selected, and later, the random selection process was applied again in order to choose houses in these streets. In every selected house, 10 employed residents were invited to participate in the research. If there were fewer than 10 residents in such house, residents of the nearest one were requested to take part in the study. The criteria for inclusion were: voluntary agreement to participate in the study, current employment for a period of no less than 1 year, and a fulltime job at only one workplace.

Two gender-matched and age-matched controls were chosen for each patient ( \pm 5 years). Altogether, 291 cases (response rate: $89.1 \%$ ) were included in the study. 582 controls were selected from 1412 questionnaires received from the residents of Vilnius. After we excluded male workers and blue-collar workers, 120 cases and 240 controls were qualified for the analysis. According to the Classification of Professions in Lithuania, the officers, managers, and specialists were embraced in the group of white-collar workers.

\section{Questionnaire}

The data was collected by means of a self-administered questionnaire. Case-respondents completed the 
questionnaires at mental health centers, while controlrespondents filled in theirs at home. After the questionnaires were returned, specialists checked them, and if some questions were unanswered, they then asked the respondents to complete them.

Personal characteristics included: gender, age, marital status, educational level, and occupational characteristics (current profession and/or position at work).

The survey devoted to psychosocial factors at work was conducted using 32 questions from the Occupational Stress Questionnaire constructed by the Finnish Institute of Occupational Health [10]. This has been adopted and used in the Occupational Medicine Centre (Lithuania) since 1998 [11]. The questionnaire also included eight questions formulated personally by the authors (marked with * below). Altogether, the questionnaire comprised 40 questions on psychosocial work factors. The internal consistency of the whole questionnaire evaluated by Cronbach's Alpha coefficient amounted to 0.857 .

The first section of the questionnaire measures regulating factors such as "decision authority", "possibility to control", "autonomy", "support”, "superior's support", "social relations", "looking out", "relations with superior*". The internal consistency of the first section of the questionnaire evaluated by Cronbach's Alpha coefficient was 0.72 .

The second section of the questionnaire measures the perceived environment, defined by 33 items such as "use of skills/knowledge", "monotony", "repetitive tasks", "hurry", "insufficient rest breaks", "work distribution", "difficult periods", "need for trainings/instructions", "mental strain", "physical strain", "work pace", "colleagues esteem", "meaning of work", "family esteem", "clarity of the work role", "clarity of the responsibility", "role conflicts", "feedback", "responsibility for other people", "responsibility for oneself", "responsibility for material values", "physical isolation", "social isolation", "comfort", "shift work*", "fear of job loss*", "multiple tasks*", "additional hours"”, "additional tasks*", "career stagnation*", "respect from administration*", "reward*". The internal consistency of the second section of the questionnaire evaluated by Cronbach's Alpha coefficient was 0.80 .

Each question had five response options and the answers were grouped into two levels - low intensity psychosocial factors (reflected by answer options 1,2,3) and high intensity psychosocial factors (reflected by answer options 4, 5). The intensity of psychosocial factors was assessed in respect of the degree (how strong) or of the frequency (how often).

Two questions on possible confounders were included in the questionnaire: personal stressful events during the previous 12 months (such as death, divorce, serious disease(s), economic problems, problems with police, problems due to family relations, loss of capital, etc.), as well as mental health disorders among family members (parents, grandparents, children, brothers, sisters, aunts, uncles, or other blood relatives).

\section{Statistical analysis}

Statistical analysis was performed using the Epi-Info 2002 program.

The following statistical methods were applied: descriptive statistic and logistic regression.

For descriptive statistics, absolute numbers and percent values were used.

The distribution of intensive psychosocial work factors was evaluated for both the cases and controls. The odds ratio (OR) with its $95 \%$ confidence interval $(95 \% \mathrm{CI})$ was estimated for each variable. For the evaluation of relations between depression and psychosocial work factors, binary logistic regression (the forward conditional method) was used. The dependent variable was depression (whether it was depression or not, according to the psychiatric diagnosis). Psychosocial factors at work were used as independent variables (low or high intensity). The variables were entered into the logistic regression model following the univariate 
analysis results, with $\mathrm{OR}>1$, and the significance level at $p<0.05$. No relationship was found among independent variables. The following potential confounders were included in the models: personal stressful events during the previous 12 months, and mental health disorders among family members. $\chi^{2}$ was used to model the evaluation, and at the level of $p<0.05$ the model was considered statistically significant. Nagelgerke $\mathrm{R}^{2}$ was also estimated.

\section{RESULTS}

The data on 360 women: 120 as cases and 240 as controls, was used in the study. The mean age in the group of cases was 39.59 (SD = 10.47), and in the control group 39.56 $(\mathrm{SD}=10.51)$. The mean concerning the number of years of employment in the current workplace was 7.73 $(\mathrm{SD}=7.28)$ in the group of cases, and $9.13(\mathrm{SD}=7.87)$ in the control group.

The majority of respondents had a university level of education. As for the marital status, about half of the respondents were married. The distribution of socio-demographic characteristics such as educational level and marital status for the cases and controls is presented in Table 1.

A prevalence data analysis showed that 3 psychosocial factors at work were more prevalent in the group of cases than in the control group, and the difference was statistically significant.

These were: work distribution (42.5\% in the group of cases and $25.1 \%$ in the control group), possibility to control $(8.7 \%$ in the group of cases and $0.8 \%$ in the control group), and family esteem (14.2\% in the group of cases and $6.7 \%$ in the control group). As resulted from the univariate analysis, the odds ratio for depression among women whose work was distributed unevenly was 2.21 (95\% CI: $1.38-3.51, \mathrm{p}<0.005)$. For those who had little possibility to exert control the odds ratio was 8.46 (95\% CI: 1.77-40.51, p < 0.005), and the odds ratio for low family esteem was 2.3 (95\% CI: 1.12-4.73, $\mathrm{p}<0.005)$. All the psychosocial factors in the univariate analysis estimations are presented in Table 2.

Table 1. Socio-demographic characteristics of female white-collar workers in the Vilnius study

\begin{tabular}{|c|c|c|c|c|}
\hline \multirow{2}{*}{ Variables } & \multicolumn{2}{|c|}{ Cases $(\mathrm{N}=120)$} & \multicolumn{2}{|c|}{ Controls $(\mathrm{N}=240)$} \\
\hline & $\mathrm{n}$ & $\%$ & $\mathrm{n}$ & $\%$ \\
\hline \multicolumn{5}{|l|}{ Education level } \\
\hline uncompleted secondary & - & - & 1 & 0.4 \\
\hline secondary & 2 & 1.7 & 13 & 5.4 \\
\hline secondary-professional & 25 & 20.8 & 56 & 23.4 \\
\hline uncompleted university & 13 & 10.8 & 23 & 9.6 \\
\hline university & 80 & 66.7 & 146 & 61.1 \\
\hline \multicolumn{5}{|l|}{ Marital status } \\
\hline married & 57 & 47.5 & 118 & 49.4 \\
\hline single & 23 & 19.2 & 42 & 17.6 \\
\hline divorced & 23 & 19.2 & 41 & 17.2 \\
\hline widowed & 10 & 8.3 & 15 & 6.3 \\
\hline cohabitation without marriage & 7 & 5.8 & 23 & 9.6 \\
\hline mental health disorders in the family & 36 & 30.0 & 36 & 15.1 \\
\hline stressful life events & 95 & 79.2 & 150 & 62.8 \\
\hline
\end{tabular}


Table 2. Univariate logistic regression analysis for psychosocial factors at work and depression represented by the odds ratio (OR) and confidence intervals $(\mathrm{CI})$

\begin{tabular}{|c|c|c|}
\hline Psychosocial factors at work & OR & $\mathrm{CI}$ \\
\hline $\begin{array}{l}\text { Decision authority } \\
\text { the person can influence matters concerning herself/himself rather little or very little }\end{array}$ & 1.71 & $0.90-3.23$ \\
\hline $\begin{array}{l}\text { Possibility to control } \\
\text { the person rather seldom or never feels that they have really accomplished something }\end{array}$ & $8.46^{* * *}$ & $1.77-40.51$ \\
\hline $\begin{array}{l}\text { Autonomy } \\
\text { work is rather dependent or very dependent }\end{array}$ & 9.09 & $0.85-11.17$ \\
\hline $\begin{array}{l}\text { Support } \\
\text { in a close circle of the person's acquaintances, there is someone with whom he/she can openly } \\
\text { discuss personal matters and problems - rather little or very little }\end{array}$ & 2.30 & $0.12-4.73$ \\
\hline $\begin{array}{l}\text { Superior's support } \\
\text { the superior provides help and support when the person needs it — rather little or very little }\end{array}$ & 1.69 & $0.97-2.96$ \\
\hline $\begin{array}{l}\text { Social relations } \\
\text { workmates get along badly (there are some problems, tensions, arguments, etc.) }\end{array}$ & 1.04 & $0.64-1.69$ \\
\hline $\begin{array}{l}\text { Looking out } \\
\text { workmates keep an eye on one another - rather often or constantly }\end{array}$ & 1.61 & $0.90-2.89$ \\
\hline $\begin{array}{l}\text { Relations with the superior } \\
\text { relations with superiors are seldom or never good }\end{array}$ & 1.86 & $0.73-4.70$ \\
\hline $\begin{array}{l}\text { Use of skills/knowledge } \\
\text { the person can use his/her knowledge and skills in his/her work — rather little or very little }\end{array}$ & 2.07 & $0.80-5.36$ \\
\hline $\begin{array}{l}\text { Monotony } \\
\text { work is rather or very monotonous }\end{array}$ & 1.28 & $0.65-2.54$ \\
\hline $\begin{array}{l}\text { Repetitive tasks } \\
\text { the person repeats the same partial task or work phase — rather often or constantly }\end{array}$ & 0.86 & $0.56-1.33$ \\
\hline $\begin{array}{l}\text { Hurry } \\
\text { the person has to hurry to get his/her work done - rather often or constantly }\end{array}$ & 1.34 & $0.86-2.08$ \\
\hline $\begin{array}{l}\text { Insufficient rest breaks } \\
\text { the person is able to take breaks or rest for a moment — rather little or far too little }\end{array}$ & 1.51 & $0.88-2.60$ \\
\hline $\begin{array}{l}\text { Work distribution } \\
\text { work is distributed unevenly — rather often or very often }\end{array}$ & $2.21^{* *}$ & $1.38-3.51$ \\
\hline $\begin{array}{l}\text { Difficult periods } \\
\text { work has phases that are too difficult — rather often or constantly }\end{array}$ & 1.64 & $0.93-2.62$ \\
\hline $\begin{array}{l}\text { Need for instructions/trainings } \\
\text { work involves tasks for which the person has too little training or too few instructions }\end{array}$ & 1.51 & $0.67-3.39$ \\
\hline $\begin{array}{l}\text { Mental strain } \\
\text { work is rather or very mentally strenuous }\end{array}$ & 1.31 & $0.84-2.04$ \\
\hline $\begin{array}{l}\text { Physical strain } \\
\text { work is rather or very physically strenuous }\end{array}$ & 2.30 & $0.14-4.65$ \\
\hline $\begin{array}{l}\text { Work pace } \\
\text { the person sets his/her work pace — rather seldom or never }\end{array}$ & 1.55 & $0.92-2.58$ \\
\hline $\begin{array}{l}\text { Colleagues' esteem } \\
\text { the work group appreciates the person's work - rather little or not at all }\end{array}$ & 1.56 & $0.77-3.18$ \\
\hline
\end{tabular}


Table 2. Univariate logistic regression analysis for psychosocial factors at work and depression represented by the odds ratio (OR) and confidence intervals $(\mathrm{CI})-$ cont.

\begin{tabular}{|c|c|c|}
\hline Psychosocial factors at work & OR & $\mathrm{CI}$ \\
\hline $\begin{array}{l}\text { Meaning of work } \\
\text { the person considers his/her work as not very important and meaningful (or not at all) }\end{array}$ & 2.46 & $0.74-8.24$ \\
\hline $\begin{array}{l}\text { Family esteem } \\
\text { the family (or a companion) appreciates the person's work — rather seldom or not at all }\end{array}$ & $2.30^{*}$ & $1.12-4.73$ \\
\hline $\begin{array}{l}\text { Clarity of the work role } \\
\text { the person is never (or usually not) given sufficiently clear instructions for work }\end{array}$ & 1.40 & $0.75-2.28$ \\
\hline $\begin{array}{l}\text { Clarity of the responsibility } \\
\text { the person has been told how he/she is responsible for his/her work — rather poorly or very poorly }\end{array}$ & 2.34 & $0.88-6.23$ \\
\hline $\begin{array}{l}\text { Role conflicts } \\
\text { superiors and workmates rather often or constantly give contradictory orders or instructions }\end{array}$ & 1.44 & $0.73-2.85$ \\
\hline $\begin{array}{l}\text { Feedback } \\
\text { the person seldom or never sees whether his/her work has been done well or poorly }\end{array}$ & 1.18 & $0.55-1.25$ \\
\hline $\begin{array}{l}\text { Responsibility for other people } \\
\text { it happens rather often or very often that work involves the risk of hurting oneself }\end{array}$ & 1.12 & $0.57-2.20$ \\
\hline $\begin{array}{l}\text { Responsibility for oneself } \\
\text { it happens often or constantly that work involves the risk that a person might hurt himself/herself }\end{array}$ & 1.11 & $0.51-2.39$ \\
\hline $\begin{array}{l}\text { Responsibility for material values } \\
\text { a person can rather often or very often accidently ruin some valuable equipment or work result }\end{array}$ & 0.76 & $0.44-1.30$ \\
\hline $\begin{array}{l}\text { Physical isolation } \\
\text { work isolates the person from others - rather often or constantly }\end{array}$ & 1.03 & $0.55-1.94$ \\
\hline $\begin{array}{l}\text { Social isolation } \\
\text { the person can talk with workmates during the workday (if he/she wants to) - rather seldom } \\
\text { or hardly ever }\end{array}$ & 1.22 & $0.62-2.42$ \\
\hline $\begin{array}{l}\text { Comfort } \\
\text { the work environment is seldom pleasant or very unpleasant }\end{array}$ & 1.51 & $0.78-2.89$ \\
\hline $\begin{array}{l}\text { Shift work } \\
\text { the person rather often or constantly works in a shift-system }\end{array}$ & 1.41 & $0.77-2.53$ \\
\hline $\begin{array}{l}\text { Fear of job loss } \\
\text { the person rather often or constantly fears losing his/her job }\end{array}$ & 1.25 & $0.79-1.94$ \\
\hline $\begin{array}{l}\text { Multiple tasks } \\
\text { the person has to do some tasks at the same time - rather often or constantly }\end{array}$ & 0.94 & $0.61-1.46$ \\
\hline $\begin{array}{l}\text { Additional hours } \\
\text { the person has to work additional hours - rather often or constantly }\end{array}$ & 1.14 & $0.7-1.84$ \\
\hline $\begin{array}{l}\text { Additional tasks } \\
\text { the person rather often or constantly receives additional tasks }\end{array}$ & 0.85 & $0.54-1.36$ \\
\hline $\begin{array}{l}\text { Career stagnation } \\
\text { the person seldom or never has the possibility to develop his/her career }\end{array}$ & 0.79 & $0.51-1.23$ \\
\hline $\begin{array}{l}\text { Respect from administration } \\
\text { the administration seldom or never shows respect for the person }\end{array}$ & 0.74 & $0.38-1.44$ \\
\hline $\begin{array}{l}\text { Reward } \\
\text { the reward for the job seldom or never corresponds to its importance }\end{array}$ & 0.73 & $0.47-1.14$ \\
\hline
\end{tabular}

${ }^{*} \mathrm{p}<0.05 ;{ }^{* *} \mathrm{p}<0.01 ;{ }^{* * *} \mathrm{p}<0.001$. 
Table 3. Binary logistic regression (the forward conditional method) analysis of psychosocial factors at work and depression represented by the odds ratio (OR) and $95 \%$ confidence intervals $(\mathrm{CI})$

\begin{tabular}{|c|c|c|c|c|c|}
\hline \multirow{2}{*}{ Variables } & \multicolumn{2}{|c|}{ Case } & \multicolumn{2}{|c|}{ Control } & \multirow{2}{*}{$\begin{array}{l}\text { Logistic regression } \\
\text { adjusted } \mathrm{OR}^{*, \mathrm{a}} \\
(\mathrm{CI}) \\
\end{array}$} \\
\hline & $\mathrm{n}$ & $\%$ & $\mathrm{n}$ & $\%$ & \\
\hline $\begin{array}{l}\text { Work distribution } \\
\text { very often, or rather often work distributed unevenly so that work piles up }\end{array}$ & 51 & 42.5 & 60 & 25.1 & $\begin{array}{c}2.17^{* *} \\
(1.32-3.56)\end{array}$ \\
\hline $\begin{array}{l}\text { Possibility to control } \\
\text { respondent never or rather seldom feels that he/she really accomplishes } \\
\text { something }\end{array}$ & 88 & 6.7 & 2 & 0.8 & $\begin{array}{c}10.81^{* * *} \\
(1.17-3.56)\end{array}$ \\
\hline $\begin{array}{l}\text { Family esteem } \\
\text { family appreciate respondent's work rather seldom or not at all }\end{array}$ & 17 & 14.2 & 16 & 6.7 & $\begin{array}{c}2.15^{*} \\
(1.01-4.59)\end{array}$ \\
\hline
\end{tabular}

Logistic regression model $\chi^{2}: 44.47$, Nagelgerke $R^{2}: 0.162$

${ }^{a}$ Adjusted for stressful life events and mental disorders in family.

${ }^{*} \mathrm{p}<0.05 ;{ }^{* *} \mathrm{p}<0.01 ;{ }^{* * *} \mathrm{p}<0.001$

We also found that the depression of the tested women was statistically significantly associated with the non-occupational stress experienced by them over the last year $(\mathrm{OR}=2.26,95 \% \mathrm{CI}: 1.35-3.77, \mathrm{p}<0.01)$. The depression of the respondents and mental health disorders of their family members were also significantly related in terms of statistics (OR $=2.41,95 \%$ CI: $1.43-4.1, \mathrm{p}<0.001)$. For the subsequent analysis we only selected the statistically significant factors associated with depression.

Logistic regression was used to evaluate the factors connected with depression and to estimate the possible impact of the confounders. Therefore, the evaluated model with its 3 psychosocial factors and the possible confounders was found to be statistically reliable (model $\chi^{2}: 44.47$, $\mathrm{p}<0.05)$. The adjusted odds ratio for work distribution was 2.17 (95\% CI: 1.32-3.56, p < 0.005), the odds ratio for possibility to control was 10.81 (95\% CI: 2.13-54.71, $\mathrm{p}<0.005$ ), and the odds ratio for family esteem equaled 2.15 (95\% CI: 1.01-4.59, $\mathrm{p}<0.005)$. The adjusted odds ratio for the confounders was 2.56 (95\% CI: $1.47-4.46$, $\mathrm{p}<0.005)$ for mental health disorders within the family, and 2.04 (95\% CI: 1.17-3.56 p < 0.005) for stressful personal life events. All the above-mentioned results are shown in Table 3.

\section{DISCUSSION}

This study adds to the growing evidence of the interrelationship between psychosocial characteristics of work and depression. It is especially important for Lithuania, where research devoted to the psychosocial environment at work has only been conducted in relation to other health conditions [12-14].

A number of authors have suggested that poor working conditions can be an important predictor of stress and may, therefore, contribute to the development of depression [15-21]. Researchers usually use job-stress models. The most popular model is Karasek's job strain model, with its main hypothesis being that the combination of high job demands along with low job control precipitates psychological and physical strain ('high strain' jobs), and serious health effects in the future [22]. Another popular model - effort-reward imbalance, was developed by Siegrist [23]. This concept emphasizes the imbalance between high effort at work and low reward received in return, where the rewards concern such aspects as money, esteem and career opportunities, including job security. This main model has been used to predict physical and mental health in a number of prospective and cross-sectional 
epidemiological studies. In the study presented hereby, we tried to identify separate work factors related to depression; therefore, it is difficult to compare the results that were obtained with many of those demonstrated by the studies described above.

Our results showed that work distribution, as well as possibility to control and family esteem are connected with depression. One factor often mentioned by other authors is social support or social relations. It is true that in other studies, researchers have often found the importance of social support of managers or colleagues for the mental health that we did not find in this study [24-27]. In Michelson's study, where the subjects were monitored for 24 years and depressive symptoms were found in $11 \%$ of the staff, the factor most associated with this disorder was poor social interaction (social contact), but not necessarily the one experienced at work [28]. Other authors also mention that interference of work with family life is an important source of job strain for females [29-30]. In addition, literature implies that women are under great stress due to their high workload and responsibilities at home [31]. Our results indicate a link between family esteem (family appreciate the person's work rather seldom, or not at all) and depression. This is crucial for Lithuania, where women traditionally dedicate more time to family, and occupy lower positions at work more often than men. In our study it was established that little possibility to control is closely linked to depression. It should be highlighted, that "little possibility to control" was understood as a situation, when a respondent rather seldom feels that he or she really accomplishes something. However, we should note that the lack of personal accomplishment might be considered as one of the depression symptoms and might also be related to bad working conditions. The survey data showed that low possibility to control was more prevalent in the group of cases than in the control group. Since the first one was composed of people with diagnosed depression, it may just indicate that the lack of personal accomplishment is more connected to depression than bad working conditions.

Various studies have suggested that major life stresses contribute to depression and depressive illnesses [32]. The tendency for depression to develop in relatives was observed by other authors as well [33]. Therefore, we used logistic regression to control the impact of these traditional risk factors of depression. The odds ratio for the three job factors remained statistically significant after adjustment.

The fact that the research only involved people with fulltime jobs and working only at one workplace can be seen as its potential limitation. Nevertheless, if we speak in particular of Lithuania, it is quite often that people perform more than a full-time job in one place, therefore the workload might be underestimated in this study and does not reflect the factual situation. We did not include questions about troublesome communication incidents (for example with clients) and bullying factors in the questionnaire, and after involving these issues, the model could be different, because many authors point out the link between these factors and depression [34-36]. In order to reduce the influence of the respondent's health status on the answers provided in the self-completed questionnaire, only respondents who had already undergone treatment (i.e., disorder symptoms were milder and a psychiatrist indicated that the health condition of the respondent is stable enough for them to participate in the survey) were taken into account. Nevertheless, the opinions of different psychiatrists varied in defining the respondent's condition as "suitable for the survey", therefore it may have had some influence on the answers.

The study included employees who were for the first time diagnosed with a depressive episode according to the ICD-10 (code F32) in mental health centers. A depressive episode was considered the only suitable diagnosis for the assessment of psychosocial factors at work since the previous history of mental disorders could 
have a negative impact on the study results. However, in some cases a depressive episode could develop into a bipolar mood disorder, schizoaffective disorder, or another kind of mental disorder or even be the onset of the respective disorders rather than be a depressive episode itself.

As the findings obtained suggest that the psychosocial factors at work are linked to depression, it is necessary to involve employers, occupational physicians and other specialists not only from the health care sector, in the prevention of depression. They should be more aware about the adverse effects of major organizational issues, on the psychosocial environment at work, and consequently on people's mental health.

\section{CONCLUSION}

This study suggests that work distribution, possibility to control and family esteem, together with stressful life events and mental health disorders in the family, are related to depression among female white-collar workers.

\section{REFERENCES}

1. Commission of the European Communities. Communication from the Commission to the European Parliament, The Council, The European Economic and Social Committee and the Committee of the Regions. Improving quality and productivity at work: Community Strategy 2007-2012 on Health and Safety at Work. Brussels, 21.2.2007. COM (2007) 62 [cited 2008 March 3]. Available from URL: http://eur-lex.europa.eu/LexUriServ/LexUriServ.do?uri=COM:2007:0062:FIN:en:PDF.

2. Mental health strategy. Approved on 03 April 2007 by the Seimas of the Republic of Lithuania No X-1070 [cited 2008 March 3]. Available from URL: http://www3.lrs.lt/pls/inter3/dokpaieska.showdoc_1?p_id=295147\&p_query= \&p_tr2=) [in Lithuanian].
3. Gabriel P. Mental health in the workplace. Situation analysis. United States. Geneva: International Labour Office; 2000.

4. Liimatainen M-R. Mental health in the workplace. Situation analysis: Finland. Geneva: International Labour Office; 2000.

5. Stanislavoviene J, Pajarskiene B, Jankauskas R, Miliajaviene J. The prevalence of the depressive state among working Vilnius residents. Med Teor Prakt 2006;12(2):169-75 [in Lithuanian].

6. Department of Statistics to the Government of the Republic of Lithuania. 2005 - results of a Lithuanian residents health survey. Vilnius: Department of Statistics to the Government of the Republic of Lithuania; 2006 [in Lithuanian].

7. Anderson P, Baumberg B. Alcohol in Europe. A public health perspective. A report for the European Commission. Luxembourg: European Communities; 2006.

8. State Mental Health Centre of Lithuania. Prevalence of alcohol and drug addiction in Lithuania in 1997-2006 [cited 2008 April 15]. Available from URL: http://www.vpsc.lt/vpsc_anglu/statistika_english.pdf.

9. State Mental Health Centre of Lithuania. Suicides in Lithuania during 1930-40 and 1986-2006 [cited 2008 March 21]. Available from URL: http://www.vpsc.lt/vpsc_anglu/statistika_english.pdf.

10. Elo AL, Leppanen A, Lindstrom K, Ropponen T. Occupational stress questionnaire: user's instructions. Helsinki: Institute of Occupational Health; 1992.

11. Pajarskiene B, Jankauskas R. Work stress impact for the efficiency index decrease in Lithuanian companies. Visuomenes Sveikata 2002;1(16):35-9 [in Lithuanian].

12. Kalinauskiene V, Theurell T, Grazuleviciene R, Azaraviciene A, Obelinis V, Azelis V. Psychosocial factors at work and myocardial infarction among men in Kaunas, Lithuania. Scand J Work Health 2005;31(3):218-23.

13. Pichart H, Bobak M, Siegrist J, Pajak A, Rywik S, Kyshegyi J, et al. Psychosocial work characteristics and self-rated health in four post-communist countries. J Epidemiol Community Health 2001;55(9):624-30. 
14. Vanagas G, Bihari-Axelsson S, Vanagiene V. Do age, gender and marital status influence job strain development for general practitioners? Medicina (Kaunas) 2004;40(10):1014-8.

11. Bourbonnais R. Are job stress models capturing important dimensions of the psychosocial work environment? Occup Environ Med 2007;64:640-1.

12. Ylipaavaniemi J, Kivimaki M, Elovainio M, Virtanen M, Keltikangas-Jarvinen L, Vahtera J. Psychosocial work characteristics and incidents of newly diagnosed depression: a prospective cohort study of three different models. Occup Environ Med 2004;61(3):219-24.

13. Agid O, Kohn Y, Lerer B. Environmental stress and psychiatric illness. Biomed Pharmacother 2000;54(3):135-41.

14. Mausher-Dorsch H, Eaton W. Psychosocial Work-Environment and depression: Epidemiologic Assessment of the Demand-Control Model. Am J Pub Health 2000;90(11): 1765-70.

19. Stansfield SA, Fuhrer R, Shipley MJ, Marmot MG. Work characteristics predict psychiatric disorder: prospective results from the Whitehall II study. Occup Environ Med 1999;56: 302-7.

20. Larish M, Joksimovic L, Knesebeck O, Starke D, Siegrist J. Effort-Reward Imbalance at Work and Depressive Symptoms. A Cross-Sectional investigation of middle-aged employees. Psychother Psych Med 2003;53:223-8.

21. Pikhart H, Bobak M, Pajak SF, Kubinova R, Topor R, Sebakova $\mathrm{H}$, et al. Psychosocial factors at work and depression in three countries of Central and Eastern Europe. Soc Sci Med 2004;58(8):1475-82.

22. Karasek RA. Job demands, job decision latitude, and mental strain: implications for job-redesign. Adm Sci Q 1979;24: 285-308.

23. Siegrist J. Adverse health effects if high-effort, low-reward conditions. J Occup Health Psychol 1996;1(1):27-4.

24. Netterstrom B, Conrad N, Bech P, Fink P, Olsen O, Rugulies R, et al. The Relation between Work-related Psychosocial Factors and the Development of Depression. Epidemiol Rev 2008;30(1):118-32. DOI 10.1093/epirev/mxn004.
25. Blackmore ER, Stansfield SA, Weller I, Munce S, Zagorski BM, Stewart DE. Major Depressive Episodes and Work Stress: Results from National Population Survey. Am J Public Health 2009;97:2088-93.

26. Niedhammer I, Goldberg M, Leclerc A, Bugel I, David S. Psychosocial factors at work and subsequent depressive symptoms in the Gazel cohort. Scand J Work Environ Health 1998;24(3):197-205.

27. Rugulies R, Bultmann U, Aust B, Burr H. Psychosocial Work Environment and Incidence of Severe Depressive Symptoms: Prospective Findings from a 5-Year Follow-up of the Danish Work Environment Cohort Study. Am J Epidemiol 2006;163:877-87.

28. Michelsen H, Bildt C. Psychosocial conditions on and off the job and psychological ill health: depressive symptoms, impaired psychological wellbeing, heavy consumption of alcohol. Occup Environ Med 2003;60:489-96.

29. Sandmark H. Work and family: associations with long-term sick-listing in Swedish women - a case-control study. BMC Pub Health 2007;7:287. DOI 10.1186/1471-2458-7-287.

30. Gamperiene M, Nygard JF, Sandanger I, Wærsted M, Bruusgaard D. The impact of psychosocial and organizational working conditions on the mental health of female cleaning personnel in Norway. J Occup Med Toxicol 2006;1:24 [cited 2007 Dec 20]. Available from URL: http://www.occup-med.com/ content///I/24.

31. Chandola T, Martijainen P, Bartley M, Lahelma E, Marmot M, Michikazu S, et al. Does Conflict between home and work explain the effect of multiple roles on mental health? A comparative study of Finland, Japan and the UK. Int J Epidemiol 2004;33(4):884-93.

32. Tennant C. Life events, stress and depression: a review of recent findings. Australian NZJ Psychiatry 2002;36:173-82.

33. Janzing JGE, de Graaf R, ten Have M, Vollebergh WA, Verhagen M, Buitelaar JK. Familiarity of depression in the community; associations with gender and phenotype of major depressive disorder. Soc Psychiatr Epidemiol 2009;44: 1067-74. 
34. Wieclaw J, Agerbo E, Mortensen PB, Burr H, Tuchen E, Bonde JP. Psychosocial working conditions and risk of depression and anxiety in the Danish workforce. BMC Public Health 2008:8-280 [cited 2009 Dec 21]. Available from URL: http://www.biomedcentral.com/1471-2458/8/280.

35. Kivimaki M, Virtanen M, Vartia M, Elovainio M, Vahtera J, Keltikangas-Jarvinen L. Workplace bullying and the risk of cardiovascular disease and depression. Occup Environ Med 2003;60:779-83. DOI 10.1186/1471-2458-8-280.

36. Hansen AM, Hogh A, Persson R, Karlson B, Garde AH, Orbaek P. Bullying at work, health outcomes, and physiological stress response. J Psychosom Res 2006;60:63-72.

This work is available in Open Access model and licensed under a Creative Commons Attribution-NonCommercial 3.0 Poland License - http://creativecommons.org/ licenses/by-nc/3.0/pl/deed.en. 